\title{
With a little help from my peers: professional development of higher education teachers to teach critical thinking
}

\author{
Gonçalo Cruz, Maria Manuel Nascimento \\ \& Caroline Dominguez
}

\begin{abstract}
:
Critical Thinking (CT) has become a fundamental competence of the 21 st century. However, university teachers still face several difficulties in promoting it through their teaching practice, mainly due to the lack of pedagogical training aimed at this purpose. In the scope of the CRITHINKEDU Erasmus+ project, a 5-day European training course for university teachers was held in Rome (Italy) aiming to engage participants with CT teaching practices and to prepare them with the required tools suitable for its development. Some teachers from the University of Trásos-Montes e Alto Douro (UTAD) attended the course as trainees, and later, along with other colleagues, assumed the role of trainers during its replication in Vila Real (Portugal). Through the analysis of a focus group of eight teachers from UTAD, the current exploratory case study aims to understand teachers' conceptions on CT and characterize how those are integrated in the teaching practices. It also tries to evaluate the impact that both training courses (as trainees and/or trainers) had on their professional development. Preliminary reflections on the implementation of $\mathrm{CT}$ teaching practices and the design of teachers training courses in this field are discussed.
\end{abstract}

Keywords:

critical thinking; teaching practice; teacher training; professional development; higher education 


\title{
Com uma pequena ajuda dos meus pares: desenvolvimento profissional de docentes do ensino superior para o ensino do pensamento crítico
}

\begin{abstract}
Resumo: O Pensamento Crítico (PC) tem-se assumido como uma competência fundamental do século XXI. No entanto, os docentes universitários enfrentam ainda diversas dificuldades para promovê-la através da sua prática de ensino, principalmente devido à falta de formação pedagógica direcionada para esse propósito. No âmbito do projeto Erasmus+ CRITHINKEDU, foi realizado em Roma (Itália) um curso Europeu de formação para docentes universitários com a duração de 5 dias, tendo o objetivo de envolver os participantes com práticas de ensino de PC, preparando-os com as ferramentas necessárias para o seu desenvolvimento. O curso foi frequentado por um grupo de docentes da Universidade de Trás-os-Montes e Alto Douro (UTAD), enquanto formandos, que posteriormente, a par de outros colegas, assumiram o papel de formadores durante a adaptação e replicação do mesmo em Vila Real (Portugal). Através da análise de um focus group de oito docentes da UTAD, este estudo de caso exploratório pretende compreender as conceções dos docentes em termos de PC e caracterizar como os mesmos integram o PC na sua prática letiva. Teve também como objetivo avaliar o impacto que ambos os cursos de formação (como formandos e/ou formadores) tiveram para o desenvolvimento profissional dos docentes envolvidos. Reflexões preliminares sobre a implementação de práticas de ensino de PC e o desenho de cursos de formação de docentes nesta área são discutidas.
\end{abstract}

Palavras-chave: pensamento crítico; práticas de ensino; formação de professores; desenvolvimento profissional; ensino superior.

\section{Avec un peu d'aide de mes pairs: développement professionnel des enseignants de l'enseignement supérieur pour enseigner la pensée critique}

Résumé: La Pensée Critique (PC) est devenue une compétence fondamentale du 21ème siècle. Cependant, les professeurs d'université rencontrent encore plusieurs difficultés pour la promouvoir dans leur pratique pédagogique, principalement en raison du manque de formation pédagogique dirigée vers cette fin. Dans le cadre du projet Erasmus+ CRITHINKEDU, un cours de formation européen de 5 jours destiné aux professeurs d'université s'est tenu à Rome (Italie), dans le but de familiariser les participants aux pratiques d'enseignement en matière de CT et de les doter avec les outils nécessaires pour son développement. Des professeurs de l'Université de Trás-os-Montes e Alto Douro (UTAD) ont suivi ce cours en tant qu'élèves. Ils ont assumé par la suite, avec d'autres collègues (UTAD), le rôle de formateurs lors de la reproduction de ce cours à Vila Real (Portugal). A travers de l'analyse d'un groupe de discussion de huit professeurs, la presente étude de cas exploratoire vise à comprendre les conceptions de la PC des ces enseignants et caractériser l'intégration du PC dans leur pratique de pédagogique. II vise aussi à évaluer l'impact des deux formations (comme élèves et/ou formateurs) sur leur développement professionnel. Des réflexions préliminaires sur la mise en œuvre de pratiques d'enseignement de la PC et sur la conception de cours de formation d'enseignants dans ce domaine sont présentées.

Mots clés: pensée critique; pratique de l'enseignement; formation des enseignants; développement professionnel; enseignement supérieur.

\section{Con un poco de ayuda de mis compañeros: desarrollo profesional de maestros de educación superior para enseñar pensamiento crítico}

Resumen: El Pensamiento Crítico (PC) se ha asumido como una competencia fundamental del siglo XXI. Sin embargo, los docentes universitarios enfrentan todavía diversas dificultades para promoverla en su práctica de enseñanza, principalmente debido a la falta de formación pedagógica dirigida a ese propósito. En el marco del proyecto Erasmus+ CRITHINKEDU, se realizó en Roma (Italia) un curso europeo de formación para docentes universitarios con una duración de 5 días, con el objetivo de involucrar a los participantes con prácticas de enseñanza de PC, preparándolos con las herramientas necesarias para su desarrollo. El curso fué frecuentado (como alunos) por algunos docentes de la Universidad de Trás-os-Montes y Alto Duero (UTAD) que asumieron posteriormente, junto con otros colegas, el papel de formadores durante la adaptación y replicación del curso en Vila Real (Portugal). A través del análisis de un focus group de ocho profesores, el presente estudio de caso exploratorio pretende comprender las concepciones de PC de los docentes y caracterizar como las integran en su práctica lectiva. Pretende también evaluar el impacto que ambos cursos de formación (como alunos e/o formadores) tuvieron para su desarrollo profesional. Reflexiones preliminares sobre la implementación de prácticas de enseñanza de PC y el diseño de cursos de formación de docentes en este campo son presentadas.

Palabras clave: pensamiento crítico; práctica docente; formación docente; desarrollo profesional; enseñanza superior. 


\section{Introduction}

Critical Thinking (CT) is at the centre of modern societies, demanding that universities prepare citizens capable of positioning themselves in today's world by seeking sustainable alternatives to the complex and immediate problems that we face every day. Nevertheless, we continue to see gaps at this level among recent graduates, based on the faulty assumption that the acquisition, permanence, and transference of CT to other contexts is per se a result of higher education (Lane \& Oswald, 2016). The effective development of CT requires strategies and environments specifically designed for this purpose, with explicit performance of authentic tasks, repetitive and deliberate practice. In other words, CT can be clearly stimulated, taught and successfully trained in our universities (Abrami et al., 2008).

According to Snyder and Snyder (2008), teachers are expected to assist their learners to think critically by explicitly and systematically questioning, examining and evaluating their judgments and decisions with specific criteria. Such activities require a practitioner's fully engagement with critical reflection, that "involves the examination of personal and professional belief systems, as well as the deliberate consideration of the ethical implications and impact of practices" (Larrivee, 2000, p. 294). Nevertheless, the path of becoming a critically reflective teacher cannot be prescribed or pre-planned, but lived as an ongoing growth process and supported on structured training programs to use and foster CT in the teaching practice (Gul et al., 2014).

However, it is a fact that teachers face several difficulties about when, where and how to teach CT throughout the curriculum. Not only because their conceptions of CT claim for greater clarity and substance (Paul, 2004), but also because CT teaching has not been properly embraced by higher education institutions (Cruz, Payan-Carreira \& Dominguez, 2017). Even in Portugal, in which the teaching of transversal competences has been increasingly valued within the quality assurance systems of the universities (Decree-Law no. 74/2006, 24 ${ }^{\text {th }}$ March $^{1}$; Decree-Law no. 107/2008, 25 th June ${ }^{2}$ ), there is no specific guidance on how CT should be taught and assessed.

In addition, and similar to several higher education systems (Becker \& Denicolo, 2013), initial training is not mandatory for university teachers. Hence, if they want to integrate CT in their own courses, they have to self-educate themselves or seek for training. This is somehow paradoxical - how Portuguese universities can promote students' CT if their teachers are not trained for that purpose?

In an attempt to bridge this gap, either in Portugal, or at a European level, the CRITHINKEDU Erasmus+ project ${ }^{3}$ promoted a five-day European training course on CT education for university teachers, in Rome, Italy. This course aimed to engage participants with $\mathrm{CT}$ teaching practices, preparing them with the required pedagogical knowledge and tools suitable for this purpose (Dominguez (coord.), 2018). The training course was 
then adapted by the webPACT professional learning community ${ }^{4}$ and replicated to the teachers of the University of Trás-os-Montes e Alto Douro (UTAD), in Vila Real, Portugal.

Thus, a focus group was carried-out with a total of eight participants, as trainees and trainers of both training experiences, respectively, in order to understand the CT conceptions of UTAD teachers and their integration into teaching practice, as well as to evaluate the impact that both training courses had on their professional development.

\section{The CRITHINKEDU Training Courses}

Two training courses for university teachers were carried-out in 2018. Both courses were drawn upon the proposals of the "European inventory of critical thinking skills and dispositions for the $21^{\text {st }}$ century" and the "Preliminary guidelines for quality in critical thinking education" (Dominguez (coord.), 2018). They included a set of integrated and complementary training sessions designed to promote and support quality teaching on $\mathrm{CT}$, providing different pedagogical tools and practical training activities within pivotal key areas, as CT learning design, teaching methods and assessment. By engaging teachers with effective instructional design principles, teaching strategies and assessment criteria for $\mathrm{CT}$, it was expected to encourage them to change the daily teaching practice with a greater focus on CT development.

The first course was delivered in Rome, Italy, between the $29^{\text {th }}$ of January 2018 to the $4^{\text {th }}$ of February 2018, and enrolled about 65 participants (50 trainees and 15 trainers) from 9 different European countries (Belgium, Czech Republic, Greece, Ireland, Italy, Lithuania, Portugal, Romania and Spain). Of those participants, eight were from UTAD/webPACT having attended the course as trainees. The course was organised according to two main types of sessions: plenary (e.g. lectures on different topics), and group work (e.g. cooperative hands-on activities). At the end of the experience, participants were expected to have been able to redesign their own courses with an explicit focus on CT development. Different topics were selected for each day (Table 1). A general overview of the training course, including the different goals, sessions and activities, can be found in Dominguez (coord.) (2018c).

Afterwards, the Rome training course was replicated with slight adaptations in Vila Real, Portugal, from the $4^{\text {th }}$ to the $17^{\text {th }}$ of July 2018 , with a total of 42 participants enrolled from UTAD: 30 trainees and 12 trainers. All the trainers were members of the webPACT.

Overall, the organization and structure of the training sessions remained the same, but some additional topics and activities were included or partially changed based on the previous findings in relation to the Rome participants' opinions (Dominguez (coord.), 2018). Namely, more emphasis and time was devoted to the introductory activities on CT teaching, as well was on CT assessment. 
Table 1 - CRITHINKEDU course topics for each day

\begin{tabular}{|c|c|}
\hline Course days & Topics for each day \\
\hline Day 1 & $\begin{array}{l}\text { What do we want to achieve in our course? } \\
\text { 1.1.An introduction on the } 4 \mathrm{C} / \mathrm{ID} \text { model } \\
\text { 1.2.Heuristic bias and CT } \\
\text { 1.3.Characterization of CT: a proposal }\end{array}$ \\
\hline Day 2 & $\begin{array}{l}\text { What students have to do? } \\
\text { 2.1.Task analysis } \\
\text { 2.2.The design of teaching sequences integrating CT } \\
\text { 2.3.Tips for designing supportive \& procedural information to deal } \\
\quad \text { with intuitive mental model }\end{array}$ \\
\hline Day 3 & $\begin{array}{l}\text { How can we support students in CT development? } \\
\text { 3.1.CT lesson planning, classroom environment, questioning, and } \\
\text { cooperative learning techniques } \\
\text { 3.2.Methods and strategies of Problem-Based Learning (PBL) } \\
\text { supporting CT development, creative thinking and visual literacy } \\
\text { 3.3.Using Values and Knowledge Education ( } \mathrm{WaKE} \text { ) for enhancing } \\
\text { CT }\end{array}$ \\
\hline Day 4 & $\begin{array}{l}\text { How can we measure the achievement? } \\
\text { 4.1.Tools to assess CT levels of your students }\end{array}$ \\
\hline Day 5 & $\begin{array}{l}\text { Are we all ready to go? } \\
\text { 5.1.Expectations after the CRITHINKEDU course }\end{array}$ \\
\hline
\end{tabular}

\section{Method}

In this exploratory case study, the focus group interview technique based on Morgan (1997) and Onwuegbuzie, Dickinson, Leech and Zoran (2009) was applied, aiming to collect the participants' views upon CT teaching practice and CRITHINKEDU training experiences, as trainees and as trainers. A focus group discussion was carried-out with eight participants of the webPACT community, from whom six attended both training experiences, in Rome (as trainees), and Vila Real (as trainers). Two participants were only trainers in Vila Real ${ }^{5}$. The participants were asked to share personal opinions and 
experiences about their CT teaching practices and participation, as trainees and trainers, in both CRITHINKEDU training courses.

\section{Research questions}

Our study aimed 1) to describe the participants' CT-related conceptions and teaching practices; and 2) to analyse in what extent the Rome and/or UTAD training courses impacted participants' professional development. In an attempt to achieve the mentioned goals, we defined the following research questions: RQ1 - How did participants understand and teach CT?; and RQ2 - In what extent the Rome and/or UTAD training course impacted participants' professional development?

\section{Participants}

The selection of participants was done using a convenience sampling approach. The following criteria were used: 1) no less than three years of CT teaching experience at UTAD and member of the webPACT community; 2) participation as trainee and/or trainer within one or both CRITHINKEDU training courses; and 3) currently developing CT teaching practices.

In order to ensure the diversity of research data, it was important that the focus group discussions involved participants from different study fields. Intentionally, no concept of CT was given to the focus groups participants. Researchers looked for authentic ideas and opinions rather than for validation of one or another theoretical concept.

One focus group was carried-out in November 2018, involving eight participants ${ }^{6}$ with a duration of 140 minutes. The sample research was constituted by one male and seven females with an age range between 41 and 65 years, representing six different study fields, namely: Psychology and Education ([PsyEdu]; $n=2)$; Statistics ([Stat]; $n=2$ ); Linear Algebra ([LAlg]; $n=1)$; Linguistics ([Ling]; $n=1)$; Engineering Management ([Eng]; $\mathrm{n}=1$ ); and Nursing ([Nurs]; $\mathrm{n}=1$ ).

\section{Procedure and data analysis}

The research process followed the Patton' conceptual research steps (2002): planning, composition, implementation and data analysis. The first step (planning) involved the preparation of different documents required to organize the focus groups, such as Invitation letter, Guidelines to researchers, Consent letter, and Thank you letter, as well as the design of the research instrument, data collection and scheduling. While creating the interview guide, twelve questions (Table 2, questions A1-C4) were generated according to three main topics: a) CT teaching practice; b) Rome course experience; and c) UTAD course experience. 
Table 2 - Focus group interview questions

\begin{tabular}{|l|}
\multicolumn{1}{|c|}{ Interview guide } \\
\hline A - As teachers of CT \\
\hline A1. What is for you "to teach for CT"? And what is being a "CT teacher"? \\
A2. What is the concept of CT that you present to your students? Is it based on any author \\
and/or theoretical model? \\
A3. In what extent CT assumes a central role in your teaching practice? What is the best \\
example of CT integration in your classroom? \\
A4. What are the largest problems faced by you and by your students when trying to \\
develop CT? \\
\hline B - As trainees of the Rome training course \\
\hline B1. What was your main motivation to attend the Rome training course? \\
B2. In which ways the Rome training course allowed you to develop and deepen your \\
concept of CT? \\
B3. What was the most significant lesson that he Rome training course provided to your \\
teaching practice? Why? \\
B4. What concrete changes have you made in your teaching practice after the Rome \\
training course? \\
\hline C - As trainers of the UTAD training course \\
\hline C1. What were the needs that you felt in the trainees that attended to the UTAD training \\
course? \\
C2. In what extent your role and training activities filled the trainees' needs and/or were \\
important to their professional development? \\
C3. The fact of being trainers helped and/or gave you new ideas to your teaching practice? \\
C4. Do you consider that there are favorable conditions to extend this training course and \\
work to other colleagues, courses and even to all the institution? Why? \\
\hline
\end{tabular}

The composition stage included the selection of participants, the invitation of participants by the research team to attend the focus group, and the scheduling of a common date for its implementation. The implementation stage started with greetings and explanation of research aim and procedure, as well as the collection of personal consents to participate in the research. The focus group discussion was conducted by a team of two researchers - moderator and moderator's assistant - in the Portuguese national language. The moderator was responsible for organizing, conducting and managing the whole focus group process, emphasizing the rules of confidentiality 
and inviting participants to ask clarification questions. All the focus group discussions were recorded in two ways: annotations and tape recording.

Data analysis started with the transcription of the audio record into the Portuguese national language. The research team made transcriptions and started the process of data analysis immediately after the focus group session. Each participant's speech was coded accordingly to the following system, assuring the confidentiality of the participants: number-of-participant_study-field. Transcript and note-based analysis were used, taken into account the notes and summary comments written by the assistant moderator.

Transcripts were analyzed using thematic analysis (Braun \& Clarke, 2006), due to its appropriateness to summarize key features of an extensive data set and identify different patterns across them. The process consisted in repeatedly reading each transcript until all relevant data items were coded and compared between researchers (Creswell, 2014). All the codes were then reviewed by two independent researchers against the entire dataset iteratively, refining them in a process of solving disagreement until a final set of themes had emerged.

\section{Findings}

Three major themes emerged separately from the data. They reveal that 1) CT teaching practice is understood as an inquiry-based process; 2) CT teaching practice can assume multiple levels of integration within the classroom; and 3) Training on CT teaching positively impacted teachers' professional development.

\section{CT teaching as an inquiry-based process}

The CT teaching practice is directly associated with an inquiry-based process. All the participants supported this resemblance between CT teaching and teaching for inquiry. Four out of eight participants highlighted this relationship associated with the promotion of students' metacognition, questioning and reflective thinking, as the example herein presented:

"Teaching for CT is to lead students to questioning themselves about the way that they achieve conclusions. Get accustomed to usually reflect about their own thinking processes (...) is to reflect on how do they take conclusions and question if they do it adequately (...) not being satisfied with the first answer, and question if they explored other sources" (P5_Ling). 
For three of the eight participants this implies the provision of opportunities to establish informed opinions or even a divergent thinking, through the analysis of alternative points of view, active listening and the seeking for the truth:

"Stop thinking in a formatted way and start thinking in a divergent manner. Provide opportunities to make opinions, confront them and verify that there are different perspectives about the same facts. Look at different perspectives about the problems and question (...) having the capacity of active listening (...) mainly to seek for the truth, having informed opinions, based on research, evidence and criteria" (P3_PsyEdu).

Others participants individually associated CT teaching with different aspects, such as rigorous thinking or efficient decision making and problem solving.

To engage with this inquiry-based practice, five of the eight participants agreed on the need to become a reflective teacher. That is a teacher who continuously engages with a student-centred approach, without never being satisfied with his/her practice, eager to improve, able to accept the students' points of view, open to different challenges, and modeler of students' thinking skills:

"A teacher who is open to question him/herself, him/her own way of thinking and being more rigorous in the way that he/she approaches the questions and allow students to question. More open, questioner and modeler of what he/she wants that students do (...) being in a constant questioning of his/her practice" (P4_Eng).

\section{CT teaching assumes multiple levels and challenges}

Although all the participants are currently integrating CT in their teaching practice, distinct levels were observed according to the following elements: frequency, explicitness and assessment. Thus, two from eight participants can be included in a higher level of teaching practice, in which they systematically, explicitly, and formally integrate CT within the course assessment. Both are from the Psychology and Education study field and didn't participate in the Rome course. These are cases in which the development of CT is more valued than the teaching of content, and promoted by structured cooperative learning and questioning strategies that are designed based on an initial diagnosis and confronted with a post-test assessment at the end of the course: 
"I'm not so concerned with delivering content; rather, to promote these skills in them [students], to solve complex problems, to give them authentic situations. This is the reflex of methodologies that l've been developing for years [cooperative learning with peer review, small and large group discussions, questioning, and concept maps], and my largest gain was this awareness of what l'm doing and also the integration with the assessment. These were my largest gains! An assessment in consonance with it. Using instruments by which I assess in a conscientious way, for sure I have a better way to adequate and facilitate what I provide to students and choose different alternatives better than others" (P6_PsyEdu).

Three from eight participants integrate CT systematically and explicitly, but do not formally assess it. Two from the eight participants integrated CT occasionally and explicitly, but did not formally assess it, and only one participant seems to promote CT occasionally, implicitly, and not formally integrated within the assessment. Such last case can be seen as a low-level integration, in which the teacher evaluates students' CT skills within three moments of the course - by presenting them multiple-choice questions in the final exams, requiring justification, explanation or demonstration - but without providing previous opportunities to practice them, or even when provided they are not assessed at all:

"Those tests have a part of multiple-choice, to force them to think. Also, in some practical classes I give them a challenge (...) to make them think and reflect on what was taught during the class (...) but I do not know if they do it, and it's also not my concern. I don't assess the challenge, but should. Is that correct? It's a good advice that you [referring to another participant] are giving to me. So, I should ask some student in the next class, randomly, and evaluate his/her work" (P1_Alg).

Some challenges were identified resulting from the attempt of integrating CT in the classroom, however they can be seen as general constraints to the teaching process commonly mentioned across all the participants. They can be institutional or studentsrelated. At the institutional level, the following were noted: large class sizes, inadequate classrooms to implement active learning, teachers' resistance to change, lack of continuous CT instruction across the curriculum, and time constraints. At the students' level, two main constraints were noted: students' learning culture (i.e. preference to expositive lecturing, "study for grades" mindset, resistance to active learning). 
Training on CT teaching positively impacted teachers' professional development

Both CRITHINKEDU training experiences were enriching and challenging to the participants. Specifically, in relation to the Rome experience, five of the six participants that attended the course as trainees exalted the opportunity to contact with different peers and to belong to the CRITHINKEDU community that is committed to improve their CT teaching practice. This social interaction and sense of belonging made them more conscious of alternative teaching practices and common difficulties within other European universities. That, in turn, gave them the self-confidence and pedagogical knowledge needed to keep improving their own practice:

"By exchanging experiences, opportunities, we not only know what the others do, but also their doubts and concerns. That part does not usually come so explicit in the literature. And that gives us more confidence because we understand that our concerns are the same of others. [In terms of pedagogical knowledge] the most significant lesson was the importance of fostering many opportunities for students' interaction in classroom. Thus, create more moments for students to talk with each other, in small groups, and debate about the topics that we [teachers] propose. This was reflected in my classroom, in the sense that now I create more moments for them to talk about the topics with peers" (P5_Ling).

Similarly, and regarding the UTAD training experience, six of the eight interviewees who were trainers agreed upon the idea that the trainees in UTAD (i.e. their peers outside the webPACT) enrolled in the experience mainly because they feel a great need for support and for opportunities to share and talk about their practices with colleagues. In other words, this can be translated as the recognition of a lack of belonging (or a need of belonging) to a professional learning community with common shared goals, as illustrated by the following excerpt:

"The desire to know other techniques and pedagogical tools, strategies, to answer to the exigencies of their courses. They [trainees] came with a concern about CT per se, truly. They wanted to make changes that go towards the CT development in their students. But I think that is mainly the need of support, of sharing. They are isolated and need to be part of something. They also lack self-confidence, that comes in detriment of the previous aspects" (P4_Eng).

Seven of the eight participants agreed that the UTAD training course clearly exceeded their expectations, having a very positive impact on the institutional teaching community and even outside of it. This was especially emphasized not only due to the great 
interest and self-confidence of the trainees in implementing CT teaching practices, but also due to the interest shown (after the course and having heard of it) by other UTAD' teachers (who didn't attend to the course) and other Portuguese universities in attending the course in future editions:

'I think that the way the course was structured responded to trainees' needs. The course created a group of support. Also, in terms of practical results, because people were unconfident at the beginning and, currently, they are implementing CT teaching practices. Our role was fundamental and positive, according to the number of teachers that keep committed. I think that possibilities became higher, because I heard from lots of people, in different schools, that there are colleagues who want to participate in future editions. I would say that it would depend on the institutional support, from the top. But yes, we are working for that, with the training certification, and because we already have requests from other institutions" (P4_Eng).

Three of the eight interviewees noted that the UTAD course was a very enriching experience for them, in the sense that it challenged their own CT and creativity to train and help colleagues from different study fields and with other teaching conceptions, to redesign their courses:

"I consider that my role was more important to open perspectives, showing them [to the trainees] that there are different things. To me, I think that was an exercise to my critical spirit and creativity, because I had to introduce myself in a group of people who were from completely different fields than mine, and from whom I had no idea of what they taught; I had to understand their teaching practice to give them an opinion, a critical evaluation, in the sense of what could improve, isn't it?" (P6_PsyEdu).

Despite this, some disagreement arose between 4 participants regarding the replication of the UTAD course in future editions. If two of them found that the course should be delivered with the same duration, structure, content and activities (i.e. in general), the other two participants thought that it must be redesigned. This idea was mainly supported due to the different levels of previous teaching training and background among the trainees, as noted by the following participant:

"Any change is slow, and in education even more. And moving from the idea of a passive student, who does not speak, participate, to an active, autonomous, self-directed student, is difficult in our minds. Generally, we never had training 
on how to plan a lesson, a course, we did not have. We have never learned to design learning objectives. Now these things are fundamental. This is such a cognitive gap. Either one dominates a taxonomy, or one has a model, or it's all done empirically. If I had to redesign the course, and I subscribe to the P6_PsyEdu's opinion, there should be more time to consolidate some aspects (...) Many seeds have been planted and are germinating. And this goes slowly: 'A long walk is made with a small step'” (P3_PsyEdu).

\section{Discussion}

What strikes here is that even experienced teachers understand and integrate CT teaching practices in different ways and levels. Thus, professional development and effective change in terms of CT teaching practices development is a complex challenge, slow and time-consuming process. In this context, both CRITHINKEDU experiences undoubtedly assumed a determinant step towards the enlargement of a professional learning community interested and committed with quality CT education.

Concerning RQ1 "How participants understand and teach CT?", the majority of teachers are congruent with an 'inquiry-based teaching' approach that, in line with Snyder and Snyder (2008), emphasizing students' questioning, metacognition, and reflective thinking through everyday life pedagogical scenarios. Their CT teaching conceptions can be closely compared with Bailin and Battersby's approach (2010), that understand inquiry as the 'process of carefully examining an issue in order to come to a reasoned judgement' (p. 4). It involves the comparative weighting of a variety of contending positions, implying both intellectual virtues and reasoning skills. Furthermore, teachers noted the need to keep a 'reflective practitioner' spirit within the process, that is: be able to accept students' points of view; eager to improve and question his/her own practice; reflect on the impact of his/her choices in terms of classroom climate, methodologies and learning situations; and focusing on students' learning, instead on the teachers' role. This was also noted by Larrivee (2000):

"The stance toward teaching practice is one of inquiry, it being in constant formation and always open to further investigation. The dance is one of experimentation and risk, modifying practice while moving to fluctuating and sometimes contrary rhythms" (p. 295).

Alike in Paul, Elder and Batell's findings (1997), some of the participants showed a quite vague understanding of what CT is and on what it takes to bring it successfully into their teaching practice. Opinions as "Thinking is reflection", "Teaching to think and not limit to statistics", or even "Teaching beyond expositive teaching", among others, 
represent responses calling for clarity and deeper understanding. Even uncritical thinkers reflect or think beyond the content, and teaching using active learning strategies does not necessarily promote CT development.

In fact, these findings seem to be related with the participants' background and experience in CT teaching, as well as with the level of CT integration in their own teaching practice. That is, teachers from the Psychology and Education study field, with several years of experience in teachers' training, even without attending to the Rome course, showed a higher level of CT integration (i.e. in which CT assumes systematically and explicitly a main role into their practice), than their peers. They seem to be more capable to elaborate a clear understanding of what CT teaching means and how it can be operationalized within their practice.

Regarding RQ2 "In what extent the Rome and/or UTAD training course impacted participants' professional development?", teachers highlighted the social dimension of both courses. That is, the opportunity provided to belong to an international and/or institutional shared space of discussion and debate with common goals, constraints and realities around CT education. This points out to what has been shown by recent studies on the social dimension of training (Waes, Bossche, Moolenaar, Maeyer, \& Petegem, 2015; Vescio, Ross \& Adams, 2008), which acknowledge the value of the professional learning communities and teachers' networks as important drivers to the learning and teaching change in higher education.

However, and potentially related with the lack of teachers' training in the overall higher education, as pointed by Becker \& Denicolo (2013), participants observed a lack of fundamental teaching skills in their peers, leading some of them to adjust future replications of the CRITHINKEDU courses to attend to different levels of teaching training knowledge and experience.

\section{Limitations}

The uneven representation (e.g. by study fields) and the small sample size cannot lead us to generalized conclusions. Data was collected and recorded in national language, and later translated into English. It might be that some ideas were fully not expressed, and/or some meaning was lost in translation. Many ideas were left out of the current research focus because their lack of conciseness and context.

\section{Final considerations}

This study highlighted the importance of community building around CT education - especially in the concrete case of CRITHINKEDU/webPACT community -, giving teachers motivation and self-confidence to explicitly reflect and discuss upon a practice with 
shared goals and difficulties. Both the aforementioned courses were a first step towards the widespread adoption of CT teaching practices within UTAD, however further scrutiny and deeper analysis is still needed on their real impact in participants' CT teaching practice. Currently, we are following the participants within their subject-matter classes, not only to assess the concrete changes to their practice, but also to analyse the value of being supported by a professional learning community like webPACT.

It seems that the questions pointed by Hager and Kaye (1992) several years ago remain unanswered today. How is CT being learnt in existing teacher training courses? Is CT a significant part of the process of effective teaching? How can teacher education providers determine whether any such development has taken place in the CT teaching practice? One thing is clear: the process is far from being simple and easy, and the research presented herein was certainly a first seed to a broader change.

\section{Acknowledgments}

This work was supported by the European Commission/EACEA under Grant 2016-1-PT01-KA203-022808. The European Commission support for the production of this publication does not constitute an endorsement of the contents, which reflect the views only of the authors, and the Commission cannot be held responsible for any use which may be made of the information contained therein.

\section{Notes:}

1 Available at https://dre.pt/application/conteudo/671387.

2 Available at https://dre.pt/application/conteudo/456200.

3 The 'CRITHINKEDU - Critical Thinking across the European Higher Education Curricula' is a project funded by the European Commission under the Erasmus+ Programme (ref. no. 2016-1-PT01-KA203-022808). More information available at http://crithinkedu.utad.pt/en/crithinkedu/.

4 The webPACT is a professional learning community which integrates academic faculty and PhD students interested in critical thinking education. More information available at http://bit.ly/webpact.

5 Due to language barriers, two of the eight participants didn't take part in the Rome training course (as trainees), namely the ones from the Psychology and Education study field. However, all of the 8 participants were trainers in the UTAD course.

6 Note: Detailed summary of focus groups participants' characteristics are available upon request to the authors.

\section{References}

Abrami, P. C., Bernard, R. M., Borokhovski, E., Wade, A., Surkes, M. A., Tamim, R., \& Zhang, D. (2008). Instructional interventions affecting critical thinking skills and dispositions: A stage 1 meta-analysis. Review of Educational Research, 78(4), 1102-1134.

Bailin, S., \& Battersby, M. (2010). Reason in the balance: An inquiry approach to critical thinking. Toronto, CA: McGraw-Hill.

Becker, L., \& Denicolo, P. (2013). Teaching in Higher Education. London: SAGE Publications. 
Braun, V., \& Clarke, V. (2006). Using Thematic Analysis in Psychology. Qualitative Research in Psychology, 3, 77-101.

Creswell, J. (2014). Research Design: Qualitative, Quantitative, and Mixed Methods Approaches (4th ed.). Thousand Oaks, CA: Sage.

Cruz, G., Payan-Carreira, R., \& Dominguez, C. (2017). Critical thinking education in the portuguese higher education institutions: a systematic review of educational practices. Revista Lusófona de Educação, 38, 43-61.

Dominguez, C. (coord.) (2018). The CRITHINKEDU European course on critical thinking education for university teachers: from conception to delivery. Vila Real: UTAD. ISBN: 978-989-704-274-4.

Gul, R. B., Khan, S., Ahmed, A., Cassum, S., Saeed, T., Parpio, Y., ... \& Profetto-McGrath, J. (2014). Enhancing Educators' Skills for Promoting Critical Thinking in Their Classroom Discourses: A Randomized Control Trial. International Journal of Teaching and Learning in Higher Education, 26(1), 37-54.

Hager, P., \& Kaye, M. (1992). Critical thinking in teacher education: A process-oriented research agenda. Australian Journal of Teacher Education, 17(2), 26-33.

Lane, D., \& Oswald, F. L. (2016). Do 45\% of college students lack critical thinking skills? Revisiting a central conclusion of academically adrift. Educational Measurement: Issues and Practice, 35(3), 23-25.

Larrivee, B. (2000). Transforming teaching practice: Becoming the critically reflective teacher. Reflective Practice, 1(3), 293-307.

Morgan, D. L. (1997). Focus groups as qualitative research (2nd ed.). Thousand Oaks, CA: Sage.

Onwuegbuzie, A. J., Dickinson, W. B., Leech, N. L., \& Zoran, A. G. (2009). A qualitative framework for collecting and analyzing data in focus group research. International Journal of Qualitative Methods, 8(3), 1-21.

Patton, M. Q. 2002. Qualitative Evaluation and Research Methods. Thousand Oaks, CA: Sage.

Paul, R. (2004). The State of Critical Thinking Today. The Critical Thinking Community website. [Available at http://www.criticalthinking.org/pages/the-state-ofcritical-thinking-today/523, retrieved in 3/12/2018].

Paul, R. W., Elder, L., \& Batell, T. (1997). California Teacher Preparation for Instruction in Critical Thinking: Research Findings and Policy Recommendations. Sacramento, CA: California Commission on Teacher Credentialing.

Silander, C., \& Stigmar, M. (2018). Individual growth or institutional development? Ideological perspectives on motives behind Swedish higher education teacher training. Higher Education, 38(2), 1-17.

Silva, I. S., Veloso, A. L. \& Keating, J. B.(2014). Focus group: Considerações teóricas e metodológicas.

Revista Lusófona de Educação, 26, 175-190. Disponível em http://revistas.ulusofona.pt/index.php/ rleducacao/article/view/4703, consultado em 5 de Setembro de 2018.

Snyder, L. G., \& Snyder, M. J. (2008). Teaching critical thinking and problem solving skills. The Journal of Research in Business Education, 50(2), 90-99. 
Van Waes, S., Van den Bossche, P., Moolenaar, N. M., De Maeyer, S., \& Van Petegem, P. (2015). Knowwho? Linking faculty's networks to stages of instructional development. Higher Education, 70(5), 807-826.

Vescio, V., Ross, D., \& Adams, A. (2008). A review of research on the impact of professional learning communities on teaching practice and student learning. Teaching and teacher education, 24(1), 80-91.

Gonçalo Cruz

Bolseiro de Investigação do Projeto 'CRITHINKEDU - Critical Thinking Across the European Higher Education Curricula' (2016-1-PT01-

KA203-022808) Universidade de Trás-os-Montes e Alto Douro (UTAD), Vila Real, Portugal

Email: goncaloc@utad.pt ORCID: 0000-0003-4738-3910

\section{Maria Manuel Nascimento}

Professora Auxiliar

Universidade de Trás-os-Montes e Alto Douro (UTAD), Vila Real, Portugal Centro de Investigação em Didática e Tecnologia na Formação de Formadores (CIDTFF), Aveiro, Portugal Email: mmsn@utad.pt ORCID: 0000-0002-3913-4845

\section{Caroline Dominguez}

Professora Auxiliar Universidade de Trás-os-Montes e Alto Douro (UTAD), Vila Real, Portugal Centro de Investigação em Didática e Tecnologia na Formação de Formadores (CIDTFF), Aveiro, Portugal

Email: carold@utad.pt ORCID: 0000-0002-8486-4142

Correspondência Caroline Dominguez Professora Auxiliar

Escola de Ciências e Tecnologia Universidade de Trás-os-Montes e Alto Douro Quinta de Prados 5000-801 Vila Real

Data de submissão: Fevereiro de 2018

Data de avaliação: Abril de 2018

Data de publicação: Julho de 2019 